\title{
Faktor Prediktor Dehisensi pada Neonatus dengan Pembedahan Abdominal
}

Lucy Pravitasari, Setya Wandita, Endy P. Prawirohartono

Bagian Ilmu Kesehatan Anak Fakultas Kedokteran Universitas Gadjah Mada, Yogyakarta

Latar belakang. Dehisensi luka operasi merupakan komplikasi operasi yang jarang, tetapi sering menyebabkan kematian. Faktor risiko yang dilaporkan adalah usia kurang dari 1 tahun, gizi buruk, hipoalbuminemia, infeksi berat, insisi median, dan operasi yang bersifat darurat.

Tujuan. Untuk mengetahui sepsis, anemia, hipoalbuminemia, trombositopenia, jenis kelamin laki-laki, operasi darurat, kurang bulan dan berat lahir rendah dapat digunakan sebagai prediktor dehisensi pada neonatus dengan pembedahan abdominal.

Metode. Dilakukan penelitian kohort retrospektif dari data rekam medis pada 159 neonatus dengan pembedahan abdominal. Analisis dilakukan dengan menghitung angka kejadian dehisensi. Analisis bivariat digunakan untuk menentukan risiko relatif dan analisis multivariat digunakan metode regresi Cox untuk mengetahui hazard rasio berdasarkan waktu terjadinya dehisensi.

Hasil. Angka kejadian dehisensi pada neonatus dengan pembedahan abdominal adalah 39/159 (24,5\%) kasus. Rerata waktu kejadian adalah hari ke-11 (kisaran 5-28 hari) pascaoperasi. Rerata lama hari rawat pasien dengan dehisensi lebih panjang, yaitu 36 (5-96) dibandingkan dengan yang tidak dehisensi $21(2-155)$ hari $(\mathrm{p}=0,001)$. Terdapat 28,2\% 11/39 (28,2\%) kasus dengan infeksi luka operasi dan angka kematian (9/39 (25\%) kasus. Tidak didapatkan faktor prediktor yang bermakna untuk terjadinya dehisensi pada neonatus dengan pembedahan abdominal.

Kesimpulan. Tidak didapatkan faktor prediktor yang bermakna untuk terjadinya dehisensi pada neonatus dengan pembedahan abdominal. Diperlukan penelitian lanjutan dengan desain yang lebih baik, yaitu secara prospektif dan mempertimbangkan faktor prediktor lain, seperti status gizi, penyakit penyerta (penyakit sistem respirasi, instabilitas hemodinamik) serta faktor intraoperatif (lama, jenis insisi dan jenis penutupan luka). Sari Pediatri 2017;19(3):131-8

Kata kunci : dehisensi, neonatus, pembedahan abdominal, faktor prediktor, luaran

\section{Predictor Factors of Abdominal Wound Dehiscence in Neonates}

Lucy Pravitasari, Setya Wandita, Endy P. Prawirohartono

Background. Abdominal wound dehiscence is a rare complication of surgery but often fatal. The risk factors from previous studies were age less than 1 year, malnutrition, hypoalbuminemia, severe infection, median incision and emergency surgery.

Objective. To determine whether sepsis, anemia, hypoalbuminemia, thrombocytopenia, male gender, emergency surgery, preterm and low birth weight (LBW) are predictors of dehiscence in neonates with abdominal surgery.

Methods. We conducted a retrospective cohort study using medical records involving 128 neonates with abdominal surgery at Sardjito Hospital, Yogyakarta in Januari 2011-December 2016. We calculated the incidence of dehiscence and relative risks with $95 \%$ confidence interval of predictors of dehiscence by multivariate analysis.

Results. The incidence of dehiscence in neonates with abdominal surgery was 39/159 (24.5\%). Average time of occurrence was day 11 (range 5-28 days) after surgery. Hospital stay was significantly longer ( $\mathrm{p}=0.001)$ in patients with mean 36 days (5-96), whereas those who were without dehiscence was 21 days (2-155). There were $28.2 \%$ (11/39 cases) with wound infections and mortality rate was $25 \%$ (9/39 cases). There is no predictor factor that statistically significant to predict the abdominal wound dehiscence in neonates. Conclusion. There is no predictor factor that statistically significant to predict the abdominal wound dehiscence in neonates. However, further research will be needed to investigate this matter. Predictor factor such as nutritional state, pulmonary disease, hemodynamic instabillity and surgery-related factors (procedure time, type of incision and type of closure) should be considered. Sari Pediatri 2017;19(3):131-8

Keywords: dehiscence, neonates, abdominal surgery, predictors, outcomes

Alamat korespondensi: Dr. Lucy Pravitasari. Bagian Ilmu Kesehatan Anak, Fakultas Kedokteran Universitas Gadjah Mada / RSUP Dr. Sardjito, Jl. Kesehatan No.1 Sekip Yogyakarta 55284, Indonesia. E-mail: dr.lucyprav@gmail.com 
Lucy Pravitasari dkk: Faktor pediktor dehisensi pada neonatus dengan pembedahan abdominal

$\mathrm{E}$ mpat juta neonatus meninggal setiap tahunnya, lebih dari 98\% kematian terjadi di negara berkembang. ${ }^{1}$ Terdapat kontribusi kematian neonatus yang tidak banyak diketahui, salah satunya adalah masalah pembedahan. ${ }^{2}$ Pembedahan pada bayi baru lahir masih merupakan tantangan utama di seluruh dunia. Perkembangan anatomis, fisiologis, metabolik, fungsi imunologis yang belum sempurna dan proses adaptasi pada kehidupan di dunia menyebabkan neonatus merupakan pasien yang unik. ${ }^{3}$

Dehisensi luka operasi adalah pemisahan sebagian atau seluruh tepi luka operasi. Angka kejadian dehisensi abdominal yang dilaporkan dari penelitian sebelumnya bervariasi antara $0,4 \%-1,2 \%$ dengan angka kematian 8\%-45\%. Di Belanda, angka kejadian dehisensi abdominal pada anak dilaporkan $0,6 \%$, dengan angka kematian 11\%. ${ }^{4}$ Angka kejadian dehisensi pasca operasi bedah mayor di Indonesia dari tahun 2005-2010 adalah 2,7\%, dengan angka kematian 14,7\%..$^{5}$ Angka kejadian neonatus dengan pembedahan abdominal yang mengalami eviserasi $2,5 \%$ dengan angka kematian mencapai 50\%. ${ }^{6}$ Dehisensi abdominal menyebabkan lama rawat menjadi lebih lama. ${ }^{4,5}$ Faktor risiko yang bermakna pada kejadian dehisensi luka operasi abdominal, di antaranya usia kurang dari 1 tahun, terutama neonatus, infeksi luka operasi, insisi median, operasi darurat, gizi buruk, hipoalbuminemia, dan kelainan di daerah colo-rectal. ${ }^{4,5,8}$

Penelitian mengenai kejadian dan faktor prediktor dehisensi pada neonatus dengan pembedahan abdominal belum pernah ada. Penelitian ini bertujuan untuk mengetahui faktor prediktor dehisensi pada neonatus dengan pembedahan abdominal.

\section{Metode}

Digunakan desain kohort retrospektif dengan mengambil data rekam medis di RSUP Dr. Sardjito sejak Januari 2011-Desember 2016. Kriteria inklusi adalah pasien neonatus dengan usia $0-28$ hari atau post-menstrual age $(\mathrm{PMA}) \leq 42$ minggu yang menjalani pembedahan abdominal dan dirawat inap di bangsal perinatal atau NICU. Kriteria eksklusi adalah rekam medis tidak lengkap. Besar sampel dihitung sesuai jenis masalah analisis komparatif kategorikal tidak berpasangan, dengan kesalahan tipe I ditetapkan $5 \%$, hipotesis satu arah $(Z \alpha=1,65)$ dan kesalahan tipe II ditetapkan 20\% (Z $\beta=0,84)$. Didapatkan besar sampel 158 orang. Variabel tergantung adalah kejadian dehisensi luka operasi. Variabel bebas adalah kadar albumin darah, kadar hemoglobin darah, angka trombosit, adanya sepsis dan hasil kultur darah (bila ada), jenis kelamin, post-menstual age, berat badan lahir, dan sifat operasi. Data dikumpulkan dari rekam medis dengan cara mengisi kuesioner. Hubungan antara variabel bebas dan tergantung diketahui dengan analisis statistik bivariat chi-square test. Dari analisis bivariat ini, variabel yang secara statistik berhubungan $(p<0,25)$ dengan kejadian dehisensi dimasukkan dalam analisis multivariat dengan metode regresi Cox untuk melihat hazard rasio berdasarkan waktu terjadinya dehisensi. Penelitian ini telah mendapatkan persetujuan dari Komite Etik Fakultas Kedokteran Universitas Gadjah Mada dengan nomor KE/FK/1179/EC/2016.

\section{Hasil}

Terdapat 159 kasus pembedahan abdominal pada neonatus di RSUP Dr. Sardjito dari Januari 2011-Desember 2016 yang memenuhi kriteria inklusi dan tidak memenuhi kriteria eksklusi. Karakteristik dasar subjek tertera pada Tabel 1.

Subjek berjenis kelamin laki-laki 95 (60,1\%) dengan rasio laki-laki dan perempuan adalah 2,2:1. Median usia subjek penelitian saat dilakukan operasi adalah 5 (IQR 2-12) hari dengan kisaran usia 0-41 hari, dan bila dilihat dari PMA, rerata adalah 38 minggu (kisaran 30-44 minggu). Rerata berat lahir neonatus yang menjalani pembedahan abdominal adalah 2.685 $( \pm 585)$ gram.

Mayoritas kasus 129 (92,8\%) bayi yang merupakan kasus rujukan. Indikasi untuk menjalani pembedahan abdominal adalah malformasi anorektal 36,7\% (58/159) kasus dan atresia saluran cerna 13,3\% (21/159) kasus. Tindakan pembedahan abdominal paling banyak adalah kolostomi $(42,7 \%)$, anastomosis $(22,6 \%)$ dan penutupan defek dinding abdomen $(11,3 \%)$.

Angka kejadian dehisensi adalah 24,5\% (39/159 kasus). Rerata waktu terjadinya dehisensi adalah hari ke-11 pasca operasi (kisaran 5-28 hari). Sebelas dari $39(28,2 \%)$ kasus dehisensi didapatkan adanya infeksi luka operasi yang dikonfirmasi dengan kultur dari dasar luka dehisensi, dengan organisme penyebabnya adalah Pseudomonas aeruginosa 2/11 (18,2\%), Acinetobacter 
Tabel 1. Karakteristik dasar subjek penelitian

\begin{tabular}{lc}
\hline Karakteristik dasar & Jumlah \\
\hline Laki-laki & $95(60,1)$ \\
Usia saat dilakukan operasi, median (IQR), hari & $5(2-12)$ \\
Post-menstrual age, rerata (SD), minggu & $38(2,45)$ \\
Kurang bulan, n (\%) & $24(15,1)$ \\
Cukup bulan, n (\%) & $135(84,9)$ \\
Berat lahir, rerata (SD), gram & $2686(585)$ \\
BBLSR, n (\%) & $2(1,3)$ \\
BBLR, n (\%) & $58(36,7)$ \\
BBLC, n (\%) & $95(60,1)$ \\
BBLB, n (\%) & $3(1,9)$ \\
Rujukan, n (\%) & $129(92,8)$ \\
Operasi darurat, n (\%) & $121(76,6)$ \\
Diagnosis, n (\%) & \\
Obstruksi saluran cerna & $119(75,3)$ \\
Malformasi anorektal & $58(36,7)$ \\
Atresia saluran cerna & $21(13,3)$ \\
Malrotasi midgut & $5(3,2)$ \\
Penyakit Hirschprung & $14(8,8)$ \\
Pankreas anulare & $10(6,3)$ \\
Duodenal web/band & $7(4,4)$ \\
Ileus & $4(2,5)$ \\
Defek dinding abdomen & $18(11,4)$ \\
Gastroschisis & $14(8,8)$ \\
Omfalokel & $1(0,6)$ \\
Hernia umbilicalis & $2(1,3)$ \\
Duktus omphalomesenterikus persisten (DOMP) & $1(0,6)$ \\
Atresia esofagus & $9(5,7)$ \\
Hernia diafragmatika & $3(1,9)$ \\
Necrotizing enterocolitis (NEC) & $4(2,5)$ \\
Tumor abdomen & $3(1,9)$ \\
Kelainan saluran cerna multipel & $2(1,3)$ \\
Tindakan, n (\%) & \\
Manipulasi usus & $131(82,3)$ \\
Kolostomi & $68(42,7)$ \\
Ileostomi/Jejunostomi & $7(4,4)$ \\
Gastrostomi & $6(3,8)$ \\
Adesiolisis & $5(3,2)$ \\
Reseksi usus & $9(5,7)$ \\
Anastomosis (termasuk Kimura, Bishop Koop dan Santuli) & $36(22,6)$ \\
Tanpa manipulasi usus & $28(17,6)$ \\
Penutupan defek dinding dada & $18(1,3)$ \\
Eksisi tumor & $3(1,9)$ \\
Release band (termasuk Ladd) & $5(3,2)$ \\
Biopsi & $1(0,6)$ \\
Anoplasti & $1(0,6)$ \\
\hline & \\
& \\
\hline
\end{tabular}


Lucy Pravitasari dkk: Faktor pediktor dehisensi pada neonatus dengan pembedahan abdominal

Tabel 2. Analisis bivariat faktor prediktor dehisensi

\begin{tabular}{|c|c|c|c|c|c|c|c|c|}
\hline \multirow{2}{*}{ Prediktor } & \multicolumn{2}{|c|}{ Dehisensi } & \multicolumn{2}{|c|}{ Tidak dehisensi } & \multirow{2}{*}{$\mathrm{p}$} & \multirow{2}{*}{$\mathrm{RR}$} & \multicolumn{2}{|c|}{ IK 95\% } \\
\hline & $\mathrm{n}$ & $\%$ & $\mathrm{n}$ & $\%$ & & & $\min$ & maks \\
\hline \multicolumn{9}{|l|}{ Jenis kelamin } \\
\hline Laki-laki & 21 & 22,1 & 74 & 77,9 & 0,50 & 0,79 & 0,46 & 1,35 \\
\hline Perempuan & 18 & 28,1 & 46 & 71,9 & & & & \\
\hline \multicolumn{9}{|l|}{ Post-menstrual age } \\
\hline Kurang bulan & 1 & 4,2 & 23 & 95,8 & 0,02 & 0,15 & 0,02 & 1,03 \\
\hline Cukup bulan & 38 & 28,1 & 97 & 78,9 & & & & \\
\hline \multicolumn{9}{|l|}{ Berat badan lahir } \\
\hline Rendah & 13 & 21,7 & 47 & 78,3 & 0,64 & 0,83 & 0,46 & 1,48 \\
\hline Cukup & 26 & 26,3 & 73 & 73,7 & & & & \\
\hline \multicolumn{9}{|l|}{ Sifat operasi } \\
\hline Emergensi & 28 & 23,1 & 93 & 76,9 & 0,61 & 0,80 & 0,44 & 1,45 \\
\hline Elektif & 11 & 28,9 & 27 & 71,1 & & & & \\
\hline \multicolumn{9}{|c|}{ Kadar albumin $(\mathrm{g} / \mathrm{dL})$} \\
\hline$<3$ & 10 & 25,6 & 29 & 74,4 & 1,00 & 1,06 & 0,57 & 1,98 \\
\hline$\geq 3$ & 29 & 24,2 & 91 & 75,8 & & & & \\
\hline \multicolumn{9}{|l|}{ Kadar hemoglobin } \\
\hline Anemia & 30 & 28,3 & 76 & 71,7 & 0,17 & 1,67 & 0,86 & 3,25 \\
\hline Normal & 9 & 17 & 44 & 83 & & & & \\
\hline \multicolumn{9}{|l|}{ Angka trombosit } \\
\hline Trombositopenia & 23 & 22,3 & 80 & 77,7 & 0,50 & 0,78 & 0,45 & 1,35 \\
\hline Normal & 16 & 28,6 & 40 & 71,4 & & & & \\
\hline \multicolumn{9}{|l|}{ Sepsis } \\
\hline Positif & 6 & 20,7 & 23 & 79,3 & 0,77 & 0,82 & 0,38 & 1,76 \\
\hline Negatif & 33 & 25,4 & 97 & 74,6 & & & & \\
\hline
\end{tabular}

baumanii, Klebsiella pneumonia, Enterobacter aerogenes, Enterobacter cloacae, Eschericia coli dan Candida albicans masing-masing 1/11 (9,1\%).

Terdapat $3(7,6 \%)$ kasus dengan dehisensi yang membutuhkan debridemen sampai dengan relaparotomi. Rerata lama rawat menjadi lebih panjang pada neonatus dengan dehisensi abdominal bila dibandingkan dengan yang tidak dehisensi ( $\mathrm{p}=0,001)$, yaitu 36 (5-96) hari, dibandingkan dengan 21 (2-155) hari. Angka kematian pada neonatus dengan pembedahan abdominal adalah 56/159 $(35,2 \%)$, sedangkan angka kematian neonatus dengan pembedahan abdominal yang mengalami dehisensi adalah 9/39 (25\%). Tidak ada perbedaan bermakna antara kematian neonatus dengan pembedahan abdominal dengan maupun tanpa dehisensi $(\mathrm{p}=0,102)$.

Analisis statistik menunjukkan bahwa BKBmemiliki probabilitas lebih rendah untuk terjadinya dehisensi (RR 0,15, IK 95\%: 0,02-1,03). Hasil analisis bivariat tertera pada Tabel 2. Variabel dengan nilai $\mathrm{p}<0,25$,
Tabel 3. Hasil analisis multivariat hazard ratio dengan regresi Cox

\begin{tabular}{lcccc}
\hline \multirow{2}{*}{ Prediktor } & \multirow{2}{*}{$\mathrm{p}$} & HR & \multicolumn{2}{c}{ IK 95\% } \\
\cline { 4 - 5 } & & & $\min$ & maks \\
\hline Kurang bulan & 0,05 & 0,14 & 0,02 & 1,01 \\
Anemia & 0,32 & 1,46 & 0,69 & 3,10 \\
\hline
\end{tabular}

dimasukkan ke dalam model analisis multivariat regresi Cox untuk melihat hazard rasio berdasarkan waktu terjadinya dehisensi (Tabel 3). Enam subjek tidak diikutkan dalam analisis regresi Cox karena meninggal sebelum terjadinya dehisensi yang paling awal, yaitu hari ke-5 pasca operasi. Dari hasil multivariat regresi Cox tidak didapatkan hazard rasio yang bermakna secara statistik baik untuk variabel kurang bulan maupun anemia.

Pembahasan 
Dehisensi merupakan komplikasi bedah sehingga proses penyembuhan luka mengalami kegagalan dan sepanjang luka insisi operasi menjadi terbuka. ${ }^{7}$ Kami mendapatkan angka kejadian dehisensi yang terjadi pada neonatus dengan pembedahan abdominal selama 6 tahun terakhir adalah 24,5\%. Angka tersebut jauh lebih tinggi dari penelitian sebelumnya karena subjek adalah neonatus yang memang diketahui menjadi faktor risiko dehisensi. Rerata waktu terjadinya dehisensi adalah hari ke-11 pasca operasi (kisaran 5-28 hari). Daya tahan spontan pada luka yang terjadi di hari pertama pasca operasi hampir tidak ada dan secara bertahap meningkat dengan waktu. Pada minggu ketiga pasca operasi, daya tahan setara dengan $20 \%$ kekuatan awal dan setelah minggu ke-6 sampai 12 kekuatan mencapai 70\%-80\%. Jahitan yang dilakukan selama proses operasi seharusnya memberikan waktu yang cukup untuk jaringan mencapai integritas struktural maupun fungsional. Umumnya, dehisensi terjadi pada hari ke- 4 sampai dengan 14 pasca operasi (rata-rata hari ke-8). ${ }^{8}$

Sebelas dari $39(28,2 \%)$ kasus dehisensi abdominal didapatkan adanya infeksi luka operasi yang dikonfirmasi dengan hasil kultur dasar luka dehisensi, yaitu Pseudomonas aeruginosa, Acinetobacter baumanii, Klebsiella pneumonia, Enterobacter aerogenes, Enterobacter cloacae dan Candida albicans dan 3 kasus tidak ada pertumbuhan kuman. Rerata lama rawat menjadi lebih panjang pada neonatus dengan dehisensi abdominal dan 3 pasien membutuhkan operasi ulang baik debridemen maupun relaporotomi karena adesi. Angka kematian pada neonatus dengan pembedahan abdominal adalah 56/159 (35,2\%), sedangkan angka kematian neonatus dengan pembedahan abdominal yang mengalami dehisensi adalah 9/39 (25\%).

Di antara 159 subjek didapatkan 16 kasus dengan kelainan kongenital multipel, 6 dengan kecurigaan sindrom Down, 7 dengan asosiasi Vacterl, 2 kecurigaan sindrom Patau, dan 1 kecurigaan sindrom Crauzer. Dari 16 subjek terdapat 2 kasus Vacterl asosiasi dengan dehisensi dan 7 kasus meninggal, yaitu 2 kasus dengan sindrom Down, 3 kasus Vacterl asosiasi serta kedua kasus sindrom Patau. Keempat kelainan kongenital ini dicurigai mempunyai gangguan pada sistem imun sehingga lebih rentan terhadap infeksi, tetapi tidak didapatkan defek langsung pada proses penyembuhan luka. Terdapat beberapa kelainan genetik yang memengaruhi penyembuhan luka, di antaranya adalah sindrom cutis laxa, sindrom Ehlers-
Danlos, homosistinuria, dan osteogenesis imperfekta. ${ }^{9}$

Tidak didapatkan faktor prediktor dehisensi yang bermakna pada neonatus dengan pembedahan abdominal. Sebagian besar pusat pelayanan medis menemukan skenario yang sulit apabila mendapatkan kasus neonatus dengan luka dehisensi tipe lengkap. Bayi kurang bulan (BKB) biasanya merupakan bayi yang sakit berat dengan infeksi aktif dan mungkin juga terjadi malnutrisi. Perkembangan otot abdomen mereka kurang baik dan penyembuhan luka dapat terganggu. Faktor lain yang mungkin berpengaruh adalah fakta yang melaporkan bahwa bayi tersebut sulit untuk mengabsorbsi makanan dari saluran cerna dan harus menggunakan total parenteral nutrition (TPN) dalam jangka waktu lama. Sistem imun BKBmasih rendah sehingga mudah terjadi infeksi luka operasi maupun dehisensi. ${ }^{10}$

Penyembuhan luka pada janin berbeda dengan dewasa, yaitu mempunyai karakteristik respon inflamasi dan pembentukan jaringan parut yang minimal. Sel imunitas masih belum berkembang, termasuk makrofag yang kurang teraktivasi dan sel-sel inflamasi mempunyai durasi hidup yang lebih pendek. Sedikitnya, sel-sel inflamasi berarti juga terdapat penurunan jumlah ekspresi dari sitokin dan faktor pertumbuhan. ${ }^{11}$ Kulit BKB masih tipis, kemerahan, dan berkerut dengan jumlah lemak subkutan yang sedikit. Bila dibandingkan dengan kulit bayi cukup bulan, kulit ini lebih lembut dan lentur sehingga mobilitasnya lebih tinggi, tetapi juga lebih lemah. ${ }^{12}$ Bayi kurang bulan tidak sama dengan janin, tetapi BKB pada awal periode pasca lahir mempunyai karakteristik yang serupa dengan janin dalam hal penyembuhan luka tanpa jaringan parut. ${ }^{13}$ Proses penyembuhan luka terjadi melalui proses pembentukan jaringan granulasi, kontraksi luka dan epitelisasi pada bagian tepi luka. Laporan kasus oleh Moon $\mathrm{dkk}^{14}$ yang melibatkan 14 kasus defek luka akibat ekstravasasi cairan intravena, melaporkan bahwa proses penyembuhan luka pada BKB mempunyai respon inflamasi dan pembentukan jaringan granulasi yang lebih sedikit, kontraksi luka yang maksimal, epitelisasi minimal sehingga pembentukan jaringan parut juga lebih kecil. Penutupan luka pada BKB terutama berkaitan dengan kontraksi luka. Respon inflamasi yang rendah membuat fase inflamasi penyembuhan luka dilewati dengan cepat sehingga langsung masuk ke dalam fase proliferasi saat terjadi kontraksi luka. Kontraksi luka adalah proses saat kulit di sekitar luka 
ditarik melingkar menuju luka yang terbuka. Proses ini merupakan bagian yang penting dalam penyembuhan luka karena dapat menurunkan ukuran defek luka tanpa pembentukan jaringan granulasi yang baru. Kontraksi luka dapat mempercepat penyembuhan luka yang lebih baik daripada penurunan ukuran luka oleh proses epitelisasi maupun jaringan parut. Besarnya kontraksi berhubungan dengan ukuran luka dan mobilitas kulit. ${ }^{14}$ Proses penyembuhan luka pada BKB masih memerlukan penelitian lebih lanjut untuk memahami mekanisme yang terjadi yang mungkin berbeda dari proses penyembuhan luka pada janin maupun pada dewasa.

Pada embrio manusia, sel-sel primitif epidermis dibentuk pada usia kehamilan 20 hari. Epidermis kemudian berproliferasi dan berdiferensiasi menjadi peridermis dan lapisan sel basal pada minggu ke-4 sampai 8 usia kehamilan. Kulit janin mulai distratifikasi pada usia kehamilan 9 minggu dan proses keratinisasi terjadi di usia 14 minggu. Pada usia 16 minggu, kulit janin sudah memiliki komponen yang hampir menyerupai kulit epidermis dewasa, yaitu lapisan sel basal, lapisan sel intermediet, folikel rambut, kelenjar keringat dan keratinisasi folikel walaupun dengan stratum korneum yang tipis. ${ }^{15}$ Bila dibandingkan dengan kulit bayi cukup bulan, epitel kulit BKB kurang berkembang, memiliki stratum korneum yang lebih sedikit dan struktur dermal-epidermal junction yang belum matur. Kondisi inilah yang mengakibatkan permeabilitas kulit BKB lebih tinggi sehingga sering terjadi kehilangan cairan secara trans-epidermal dan lebih mudah terinfeksi. ${ }^{16}$ Stratum korneum BKB lebih tipis sehingga fungsi sawar epidermis juga masih belum sempurna, terutama pada bayi dengan umur kehamilan kurang dari 34 minggu. ${ }^{17}$

Cohen dan Slegfield ${ }^{18}$ menyatakan bahwa sel mesodermal yang terletak di bawah epidermis memproduksi MES yang terdiri dari glikosaminoglikan. Asam hialuronat merupakan glikosaminoglikan yang utama diproduksi saat trimester pertama. Protein matriks juga disintesis di trimester pertama, termasuk serat imatur yang menyerupai elastin dan kolagen tipe I, III, V dan VI. Kolagen tipe III dan V pada bayi memiliki jumlah yang lebih banyak dibandingkan dewasa. Pada usia 3 bulan, dermis akan bertransformasi menjadi jaringan ikat, bersamaan dengan diferensiasi epidermis. Pada bulan ke-3 sampai ke-5, ukuran dan jumlah matriks protein akan bertambah dan mengubah komposisi glikosaminoglikan. Sel-sel imigran, termasuk sel Schwann, sel Merkel, melanoblas, pericyte dan sel mast ditemukan di dermis pada bulan ke-5. Dermis akan terus berkembang sampai usia 6 bulan pasca lahir.

Penyembuhan luka merupakan proses yang kompleks dan nutrisi berperan penting pada pembentukan jaringan baru. Status nutrisi yang adekuat juga penting untuk mencapai sistem imun yang kompeten untuk mencegah infeksi saat sawar kulit mengalami kerusakan. ${ }^{17}$ Respon tubuh terhadap luka yang ditimbulkan melalui trauma, pembedahan atau cedera adalah dengan cara meningkatkan kebutuhan protein. Pada awalnya, terdapat penurunan metabolisme akibat adanya trauma, tetapi akan meningkat kembali dan dibutuhkan protein yang cukup yang diambil dari cadangan tubuh. Akibatnya, lemak dan massa tubuh akan dipecah untuk memberikan ekstra energi. Hal ini disebut proses katabolik. Setelah operasi, diperlukan nutrisi tambahan untuk proses penyembuhan luka. ${ }^{19}$ Penyembuhan luka juga membutuhkan tambahan kalori, protein, vitamin C, vitamin A, zink, magnesium, tembaga, dan zat besi. Namun, kebutuhan tambahan ini mungkin sulit dilakukan pada bayi yang sakit atau sangat kurang bulan, terlebih lagi pada kondisi yang memerlukan restriksi cairan atau toleransi terhadap nutrisi yang kurang baik. ${ }^{17}$ Pada penelitian kami, penilaian status gizi hanya berdasarkan berat badan lahir dan kadar albumin dalam darah, tidak dilakukan pemantauan perubahan berat badan antara saat kelahiran dan waktu operasi. Akan lebih baik jika berat badan yang dipakai adalah berat badan sesaat sebelum dilakukan operasi sehingga prediksi mungkin akan lebih tepat.

Hipoalbuminemia dan anemia dapat meningkatkan kemungkinan terjadinya dehisensi, walaupun pada penelitian kami tidak didapatkan hasil statistik yang bermakna. Kadar albumin serum merupakan prediktor yang baik dan sederhana untuk terjadinya komplikasi operasi dan berhubungan dengan derajat malnutrisi. ${ }^{20}$ Tidak didapatkan perbedaan antara kadar albumin pasien dengan dehisensi maupun tidak. Pasien dengan hipoalbuminemia (albumin $<3,5 \mathrm{~g} / \mathrm{dL}$ ) mempunyai kemungkinan 16 kali lebih besar untuk terjadinya dehisensi bila dibandingkan dengan yang memiliki kadar albumin normal. ${ }^{21}$ Hipoproteinemia berhubungan dengan penyembuhan luka yang buruk karena terdapat penurunan sintesis kolagen pada luka operasi maupun tempat anastomosis. ${ }^{22,23}$ Hipoproteinemia menghambat respon imun, yaitu aktivasi makrofag dan 
pembentukan granuloma. Pada pasien dengan hipoalbuminemia, sering terjadi infeksi luka, septikemia, dan kebocoran anastomosis. ${ }^{24}$ Hipoproteinemia memperpanjang fase inflamasi dan menganggu fibroplasia, proliferasi pro-teoglikan, dan sintesis kolagen sehingga meng-hambat neoangiogenesis serta proses remodeling. ${ }^{21}$

Anemia merupakan faktor yang berpengaruh pada penyembuhan luka yang buruk. Namun hal ini masih menjadi perdebatan. Mann $\mathrm{dkk}^{25}$ dan Marsh $\mathrm{dkk}^{26}$ menyatakan bahwa anemia, bila tidak disertai dengan defisiensi di faktor lain tidak berhubungan dengan kejadian dehisensi secara signifikan. Heughan $\mathrm{dkk}^{27}$ menyimpulkan bahwa penyembuhan luka akan terganggu oleh kondisi yang berhubungan dengan anemia, seperti malnutrisi, volume sirkulasi darah yang rendah, dan peningkatan viskositas darah karena trauma. Pada penelitian kami, hasil pemeriksaan laboratorium yang digunakan sebagai prediktor adalah hasil terakhir sebelum dilakukan operasi sehingga apabila terdapat hasil yang di bawah standar dari bagian anestesi sudah mengalami perbaikan terlebih dahulu dengan cara transfusi. Alasan digunakan hasil laboratorium sebelum operasi adalah untuk mengurangi bias. Kejadian saat operasi seperti perdarahan maupun infeksi yang terjadi intraoperasi sangat mungkin mengganggu hasil laboratorium pasca operasi. Hal ini mungkin menjadi penyebab kadar albumin dan hemoglobin darah antara subjek dengan ataupun tanpa dehisensi tidak bermakna.

Pada penelitian kami tidak didapatkan perbedaan terjadinya dehisensi dengan adanya sepsis neonatorum. Penelitian Yılmaz $\mathrm{dkk}^{28}$ melaporkan bahwa infeksi yang terjadi pada luka operasi akan memengaruhi dinding perut dan menjadi penyebab utama munculnya hernia insisional ataupun dehisensi, yaitu adanya infeksi yang terjadi mempunyai hubungan yang bermakna dengan kejadian dehisensi. Ramhorst $\mathrm{dkk}^{4}$ dan Meilany $\mathrm{dkk}^{5}$ menyebutkan bahwa sepsis pre-operasi dapat meningkatkan kemungkinan terjadi dehisensi, masing-masing 3,7 kali dan 10,7 kali lebih tinggi. Pada penelitian kami, kriteria sepsis berdasarkan adanya pertumbuhan kultur kuman dengan sampel darah yang diambil sebelum operasi. Adanya pertumbuhan kuman pada hasil kultur didapatkan pada 50\%-60\% pasien sepsis di NICU RSUP Dr.Sardjito. Namun, sepsis yang didapatkan saat maupun setelah operasi juga mungkin turut andil dalam kejadian dehisensi.

Kelemahan pada penelitian kami adalah menggunakan desain retrospektif dan data sekunder dari rekam medis sehingga terdapat beberapa data yang tidak lengkap dan bias informasi. Termasuk di dalamnya adalah data subjek untuk umur kehamilan yang didapatkan berdasarkan anamnesis tercantum pada rekam medis, hanya beberapa yang mengonfirmasi dengan skor Dubowitz sehingga untuk penentuan postmenstrual age yang dimasukkan sebagai data juga dapat terjadi bias informasi. Hal tersebut dapat berkontribusi untuk ketidaksesuaian hasil penelitian bila dibandingkan dengan teori dan literatur sebelumnya. Data-data lain yang kurang lengkap yang mungkin dapat berpengaruh terhadap dehisensi adalah lama operasi, jenis benang operasi, teknik penutupan luka, dan jenis operasi (bersih, terkontaminasi, atau kotor).

\section{Kesimpulan}

Tidak didapatkan faktor prediktor yang bermakna untuk terjadinya dehisensi pada neonatus dengan pembedahan abdominal. Proses penyembuhan luka pada neonatus terutama jika bayi lahir kurang bulan masih memerlukan penelitian yang lebih lanjut untuk memahami mekanisme yang terjadi yang mungkin berbeda dari proses penyembuhan luka pada janin maupun pada dewasa. Diperlukan penelitian lanjutan dengan desain yang lebih baik, yaitu secara prospektif dan mempertimbangkan faktor prediktor lain, seperti status gizi, penyakit penyerta (penyakit sistem respirasi, instabilitas hemodinamik) serta faktor intraoperatif (lama, jenis insisi dan jenis penutupan luka).

\section{Daftar pustaka}

1. Opara P, Ujuanbi A, Okoro P. Surgical admissions in a newborn unit in a low resource setting, challenges in management and outcomes. J Neonatal Biol 2014;3:1-5.

2. Ugwu RO, Okoro PE. Pattern, outcome and challenges of neonatal surgical cases in a tertiary teaching hospital. African J Pediatr Surg 2013;10:226-30.

3. Osifo D, Oriaifo I. Factors affecting the management and outcome of neonatal surgery in Benin City , Nigeria. Eur J Endocrinol 2008;18:107-10.

4. Ramshorst G Van, Salu NE, Aronson DC, Lange JF. Risk factors for abdominal wound dehiscence in children : A casecontrol study. World J Surg 2009;33:1509-13.

5. Meilany TA, Arianto A, Bausat Q, Prihartono J, Sjarif DR. 
Lucy Pravitasari dkk: Faktor pediktor dehisensi pada neonatus dengan pembedahan abdominal

Pengaruh malnutrisi dan faktor lainnya terhadap kejadian wound dehiscence pada pembedahan abdominal anak pada periode perioperatif. Sari Pediatr 2012;14:110-16.

6. Çiğdem MK, Onen A, Otçu S, Duran H. Postoperative abdominal evisceration in children: possible risk factors. Pediatr Surg Int 2006;22:677-80.

7. Nadir A, Kaptanoglu M, Sahin E, Sarzep H. Post-thoracotomy wound separation (dehiscence): A disturbing complication. Clin Sci 2013;68:1-4.

8. Kenig J, Richter P, Żurawska S, Lasek A, Zbierska K. Risk factors for wound dehiscence after laparotomy - clinical control trial. Pol Przegl Chir 2012;82:565-73.

9. Broughton G, Janis JE, Atinger CE. Wound healing : an overview. Plast Reconstr Surg 2006;117:1-32.

10. Burki T, Misra D, Ward H, Patricolo M, Cord-Udy C. Conservative management of major abdominal wound dehiscence in premature babies - A seven-year experience. Eur J Pediatr Surg 2009; 19:232-5.

11. Rolfe KJ, Grobbelaar AO. A review of fetal scarless healing. ISRN Dermatol 2012; doi:10.5402/2012/698034.

12. Longaker MT, Peled ZM, Chang J, Krummel TM. Fetal wound healing : progress report and future directions. Surgery 2001;130:785-7.

13. Eun S. Prognosis of full thickness skin defects in preterm infants (discussion). Plast Reconstr Surg 2012;39:469-70.

14. Moon HS, Burm JS, Yang WY, Kang SY. Prognosis of fullthickness skin defects in premature infants. Arch Plast Surg 2012;39:463-9.

15. Yagi LH, Watanuki LM, Isaac C, Gemperli R, Nakamura YM, Ladeira PRS. Human fetal wound healing : a review of molecular and cellular aspects. Eur J Plast Surg 2016. doi:10.1007/s00238-016-1201-y.

16. Forest-Lalande L. Helpful hints in neonatology wound care. Diunduh pada 23 Oktober 2017. Didapat dari : https://www. researchgate.net/publication/238077695_Helpful_hints_in_ neonatology_wound_care.

17. Fox MD. Wound care in the neonatal intensive care unit.
Springer Publ Compaby 2011;30:291-303.

18. Cohen B, Slegfield E. Dermatologic Condition. Dalam: Avery's disease of the newborn. Edisi ke-8. Washington: Saunders; 2005.h. 1471-3.

19. Russell L. The importance of patient nutritional status in wound healing. Br J Nurs 2001;10:S42-9.

20. Abdel-Sattar Hussein AF, Fares KM, Mostafa MA, Mohamed $S$, Hamed HB, Gomaa Hagras AM. Implication of hypoalbuminemia in early postoperative complications. SECI Oncol 2015;3:8-13.

21. Talukdar M, Sankamithra G, Paul R, Shaan AR. Clinical study on factors influencing wound dehiscence in emergency exploratory laparotomy. J Evol Med Dent Sci 2016;5:1934-38.

22. Haukipuro K, Melkko J, Risteli L, Kairaluoma MI, Risteli J. Connective tissue response to major surgery and postoperative infection. Eur J Clin Invest 1992;22:333-40.

23. Windsor JA, Knight GS, Hill GL. Wound healing response in surgical patients : recent food intake is more important than nutritional status. Br J Surg 1988;75:135-7.

24. Gibbs J, Cull W, Henderson W, Daley J, Hur K, Khuri SF. Preoperative serum albumin level as a predictor of operative mortality and morbidity. Arch Surg 1999;134:36-42.

25. Mann LS, Spinazzola AJ, Lindesmith GG, Levine MJ, Kuczerepa W. Disruption of abdominal wounds. J Am Med Assoc 1962;180:1021-3.

26. Marsh RL, IJWC, Angeles L, Ross WL, Stevens GA, Hills B. Factors involving wound dehiscence. J Am Med Assoc 1954;155:1197-9.

27. Heughan C, Grislis G, Hunt TK. The effect of anemia on wound healing. Ann Surg 1974;179:163-7.

28. Yılmaz KB, Akıncı M, Doğan L, Karaman N, Özaslan C, Atalay C. A prospective evaluation of the risk factors for development of wound dehiscence and incisional hernia. Ulus Cer Derg 2013;29:25-30. 